\title{
Review and assessment of environmental impacts of ecological disasters on biodiversity in Anambra state, Nigeria
}

\begin{abstract}
Anambra State of Nigeria as well as other neighboring States and most of the other African countries suffer from major ecological disasters that pose much negative environmental effects on Biodiversity; that have also resulted in terminal changes on the lives of plant and animal species in the total environment as glaringlymirrored from Geological and Environmental Sciences field and laboratory studies and research. Climate change that results through natural and anthropogenic activities into high temperatures, heat waves, wind/sand/dust storms, excessive aridity, heavy rainfall, flooding, soil and gully erosion and landslides; environmental pollution and contamination; desertification; deforestation and urbanization; hunger, poverty and disease; greed, ignorance, poor professional attitude, fraud and corruption are some of the major environmentally-destructive factors that adversely-derail Biodiversity resources. Many varieties of plant and animal species and wildlife have been terminally-lost; by which all losses affecting parts of the Tropics of African countries are trending fast to an emerging regional biotic extinction within this Holocene (Recent) times. The present attitude by governments and people of all affected areas including Anambra State as a case example to Biodiversity losses is of a laissez-faire attitude and unscientific nature; officials do not seem to care. Also the public does not seem to care on the outcome. National governments, national and international aid agencies, institutional and corporate bodies, professionals and other individuals must change their attitude and acts to proffer better understanding to problems-solution and provide more moral and intellectual support and funding to experts and professionals for studies, research and effective local, national and regional control measures to check the massive terminal losses in Biodiversity in the environment.
\end{abstract}

Volume 3 Issue 2 - 2019

\section{Boniface CE Egboka, Elizabeth I Okoyeh \\ Department of Geological Sciences \& sub-Department of Applied Geophysics, Nnamdi Azikiwe University, Nigeria}

Correspondence: Boniface CE Egboka, Department of Geological Sciences \& Sub Department of Applied Geophysics, Nnamdi Azikiwe University, Awka,Anambra State, Nigeria, Email boniegboka@gmail.com

Received: February II, 2018 | Published: April 0I, 2019

\section{Introduction}

Biodiversity deals with components of "Bio or Life" and "Diverse" or varieties of environmental elements that affect life positively or negatively. Biodiversity issues require holistic and broad-based study/problem-solutions approach through the use of integrated, multitechnique and multiobjective measures in handling arising issues or solving the problems. As one writes on Biodiversity from the background and experience of field observations over the years Geology and Environmental Sciences, one realizes that professionals from different fields of endeavor should be encouraged to be part of problem-solutions. Anambra State is one of the fastest growing States out of the $36 \mathrm{No}$. States in Nigeria (Figure 1). Anambra State is thickly-populated and compact with diverse socioeconomic and industrial activities (Figure 2). The State has lost a great deal vis-a-vis Biodiversity as a result of diverse negative impacts of many ecological disasters that hazard the environment; as many of the wildlife in form of plants and animals have gone out of existence. The high population density and crowded nature of the population of the State as well as the nature of human settlements within urban, semi/peri-urban and rural communities tend to defy proper classification of Demographic nature of Anambra State. The situation has adversely-affected Biodiversity of human beings, animal and plant lives. Wildlife and highly-needed plants, fruits and vegetables for food and medicinal purposes are terminally-lost as critically-observed for many years.

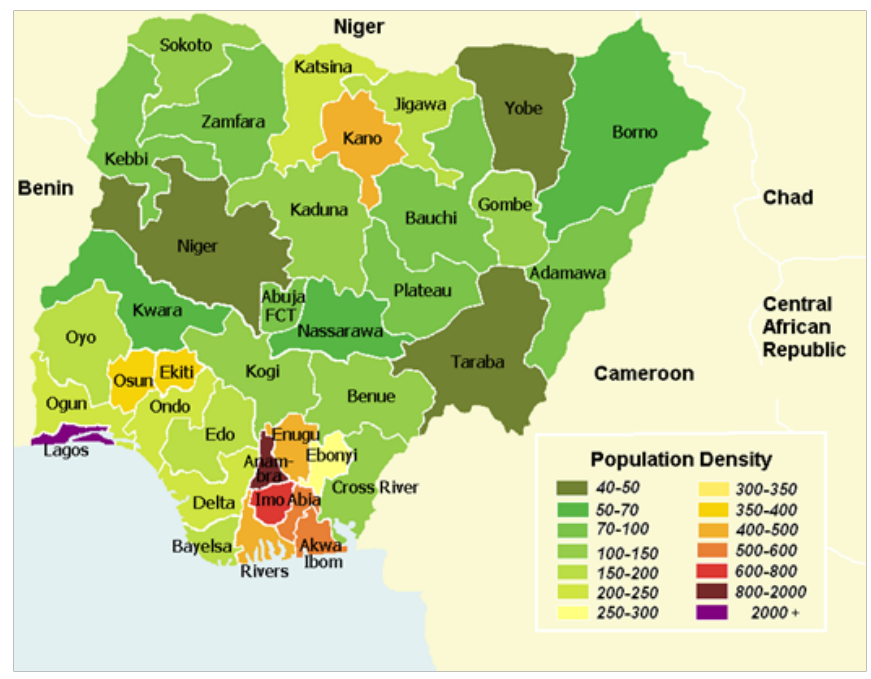

Figure I Map of Nigeria showing population density of different states of the federation (Source:Wikipedia).

The term, Biodiversity, must be well-understood and fullyappreciated on a wider scale so that one can articulate issues properly in order to possibly-solve the arising environmental/ecological problems from its negative global and high-level effects. Meaning of Biodiversity 
is a composite of 'bio' (life) and 'diversity', a state of being diverse or having variety generally refers to the variety and variability of life on Earth. Biodiversity measures variation at genetic level the species and ecosystem level (UNEP). Terrestrial Biodiversity tends to be greater near the Equator which seems to be the result of warm climate high primary productivity. Biodiversity is not distributed evenly on Earth, and is richest in the Tropics. These tropical forest ecosystems cover less than 10 percent of earth's surface and contain about 90 percent of the world's species. There are latitudinal gradients in species diversity. Biodiversity generally tends to cluster in hotspots and has been increasing through time but will likely slow down in the future. Rapid environmental changes cause mass extinction. More than $99.9 \%$ of all species that ever lived on Earth, amounting to over five billion species are estimated to be extinct. Estimates on the number of Earth's current species range from 10 to 14 million of which about $1.2 \mathrm{~m}$ has been documented and over 86 percent have not been described. More recently, in May 2016, scientists reported that 1 trillion species are estimated to be on Earth currently with only one-thousandth of one percent described. Since life began on Earth major mass extinction shave led to large and sudden drops in Biodiversity. Growth in Biodiversity via the Cambrian explosion in the last $540 \mathrm{~m}$ years marked a rapid growth during which the majority of multicellular Phyla first appeared. The next $400 \mathrm{~m}$ years included repeated losses in Biodiversity classified as mass extinction events. In Carboniferous period, rainforest collapse led to a great loss of plant and animal life. The Permian-Triassic extinction event, $251 \mathrm{~m}$ years ago, was the worst; vertebrate recovery took $30 \mathrm{~m}$ years. The most recent Cretaceous-Palaeogene extinction that occurred $65 \mathrm{~m}$ years ago resulted in the extinction of the dinosaurs. The period since the emergence of humans has displayed an ongoing Biodiversity reduction named the Holocene or Recent extinction primarily caused by human impacts by habitat destruction.

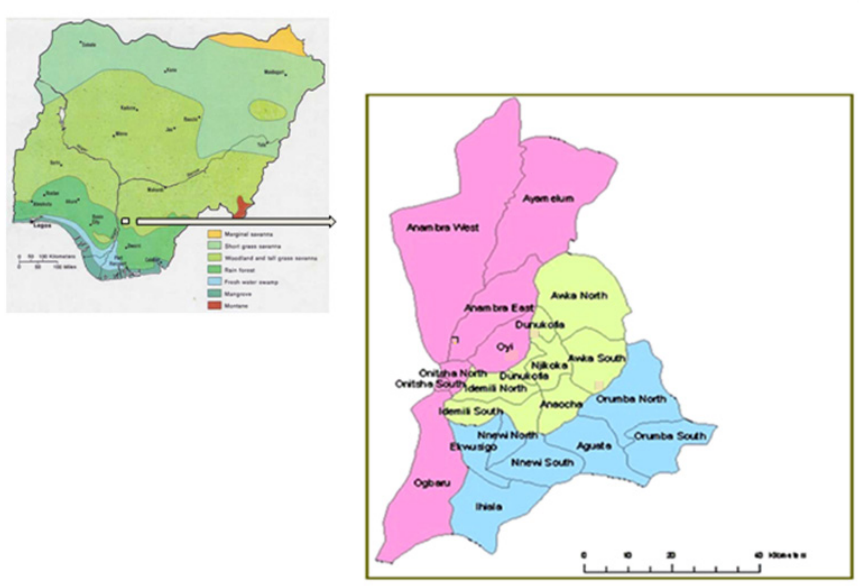

Figure 2 Map of Anambra State showing urban and Peri-Urban communities.

\section{Impacts of demography, pedology, geography, geology and hydrogeology}

Demography (population impacts), Pedology (soils effects), Geography (surface features), Geology (rocky/subsurface soil/rock materials), Hydrogeology (water resources) etc. are fundamental elements in Applied Sciences that drive the machineries and engines of Biodiversity changes; they are surface and subsurface features, human beings, soils, solid and soft rocks and water elements that convey data or issues on Biodiversity with which it is studied, described and learned. Anambra State of Nigeria has Anambra River which flows through the area as a tributary of the River Niger (Figures $1 \&$ Figure $3)$. Water quality devaluation constitutes a major environmental and socioeconomic problem. ${ }^{1}$

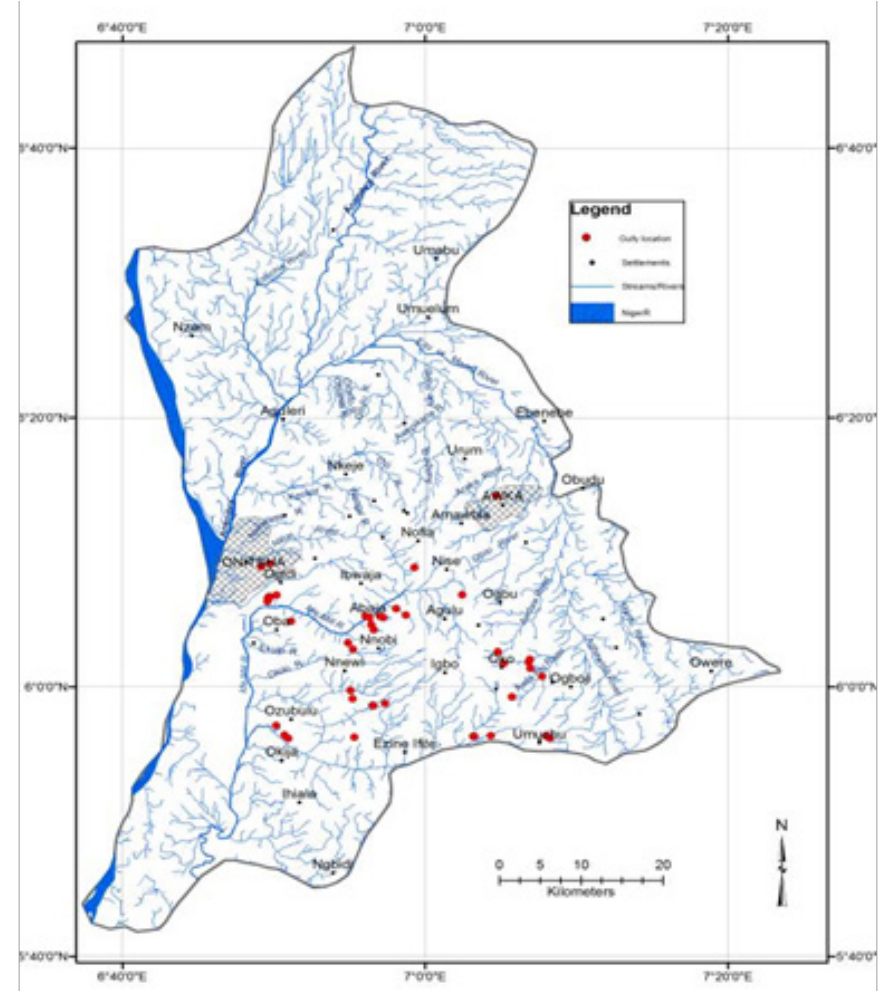

Figure 3 Drainage map of Anambra State (Source: Geohazards, Awka).

The indigenous ethnic groups in Anambra State are the Igbo (98\%) and a small population of Igala (2\%). The stretch of more than $45 \mathrm{~km}$ distance between the towns of Oba and Amorka contains numerous thickly populated villages and small towns, giving the area an estimated thick average density of 1,500-2,000 persons per sq. km. The State is rich in natural gas, crude oil, bauxite, lignite, quartz sands/ironstone and kaolinite for ceramics-making. It has an almost $100 \%$ rich arable lands of clayey soils inter-layered with silty and sandy materials with sometimes overlying red earth of lateritic soils. Anambra State is famous for its acidic soils of southeastern Nigeria with $\mathrm{pH}$ of about 5 that also occur in places as thick erodible layers of sandy soils sometimes as thick as $15-20 \mathrm{~m}$. Other economic resources include agro-based activities such as fisheries and farming. Anambra State is one of the thirty-six States of Nigeria with a thick population of over four million $(4,182,032)$ people who are mainly of the hardworking, entrepreneurial and industrious Igbo ethnic group. The State is embedded in thick vegetation of Tropical Rainforest Belt. Unfortunately over $80 \%$ of Rainforest Belt has been lost as result of active deforestation, urbanization, floods, soil and gully erosion, landslides, other anthropogenic activities and adverse impacts of climate change.

Geomorphologically, Anambra State has scarp slopes, rolling hills, valleys and lowlands with patches of ancient forests dotted here and there around ancient shrines as well as springs, lakes, streams and rivers that cover parts of the landscape. The State is bounded in the west by Delta State and Imo State; Rivers State to the south; Enugu State to the east; and Kogi State to the north. Major urban centres include Awka, State capital, Onitsha, Nnewi, Ekwulobia etc. There are 
peri/semi-urban and rural communities. The area is almost separated into halves by north-south trending hilly/upland of Awka-EkwulobiaUmuchu-Orlu escarpment/ cuesta with the steep scarp slope trending to the east and gentle dip slope trending to the west. This Geology with its north-south trending major escarpment together with other smaller ones control to a great extent the Hydrology and Hydrogeology of the environment whereby springs, lakes, streams and rivers issue out from both sides/flanks of the slopes/flanks of the cuesta (Figure $3 \&$ Figure 4). The escarpment has a crest that stands $350 \mathrm{~m}$ above mean sea level forming surface water groundwater divides. ${ }^{2}$ The State is overlain and underlain by sandy Nanka Formation underlain by clayey Imo Shale. ${ }^{3}$

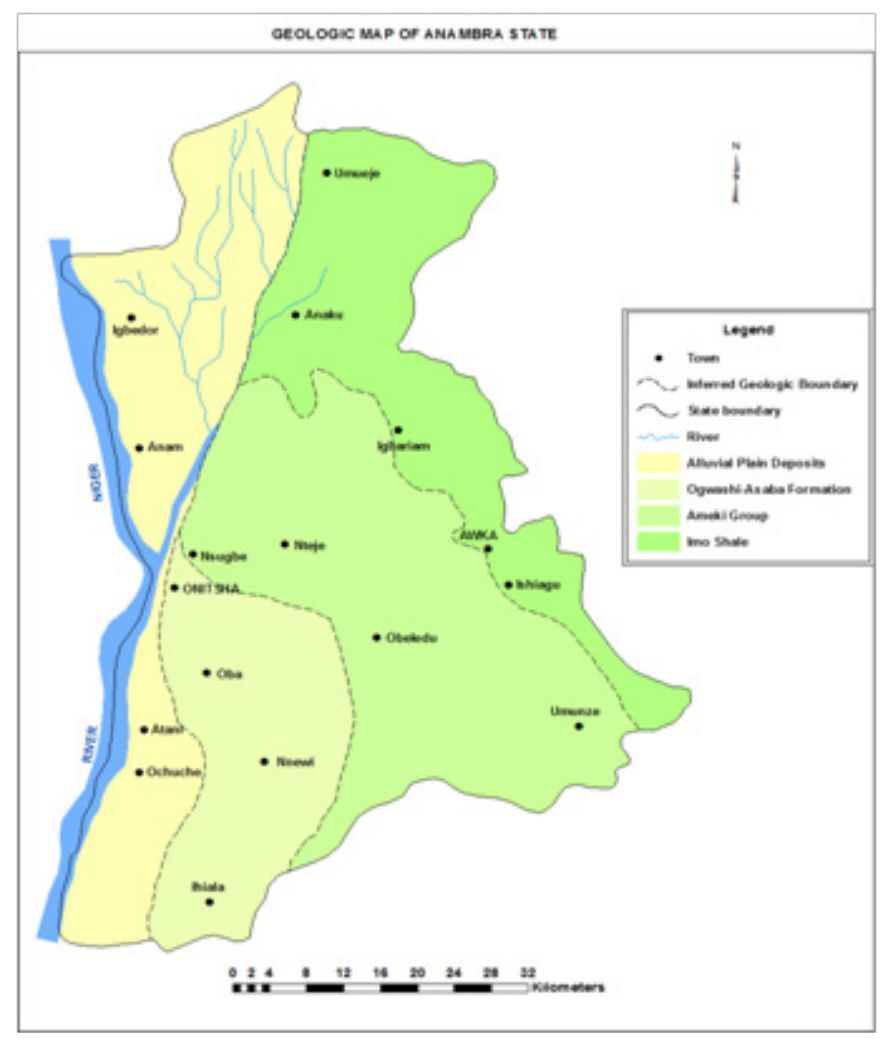

Figure 4 Geologic map of Anambra State (Source: Geohazards, Awka).

Below the ground surface and within the sedimentary sandy/clayey units are found huge and high-yielding water-bearing unconfined or watertable aquifers and confined aquifers. The major surface waters in the area are springs, lakes, streams while the Rivers are Anambra, Obizi, Idemili, Ezu, Aghomili, Uchu etc. They emerge from huge groundwater aquifers beneath the escarpment and flow eastwards into the Imo River or westwards into the River Niger; both waterflows of which eventually empty southward through their deltas into the Atlantic Ocean. Along the flow systems of these major rivers are heavy deposits of sands due to upland soil and gully erosion that are commercially-mined and sold for construction purposes. Much of the heavy loads of sand deposits are being dredged presently for commercial purposes in the River Niger (Egboka and Okoyeh, 2016). These rivers transport these heavy loads of sediments over the years to form huge source rock-materials for the sedimentary Formations of the Mono-Economy based oil-wealth of the petroleum and natural gas-rich Niger Delta of Nigeria.

The impacts of climate change have also become quite obvious in parts of Anambra State and environs with its severe concomitant negative impacts/effects on environmental Biodiversity. Northern parts of the State have more of harsh climatic conditions of Guinea Savannah type of environment with brush and shrubby vegetation thereby displacing the former rich green-virgin Rainforest Belt in the area. This is the result of downward ingress of the Sahara desert/ Sahel climatic conditions owing to desertification phenomenon. There are two major seasons, namely, the rainy season (April to October) and dry season (November to March). Average annual rainfall during the rainy season is about $2000 \mathrm{~mm}$ with high humidity, frightening thunderstorms and heavy flooding that usually occurs. During dry season, the temperature is high at about $29-32^{\circ} \mathrm{C}$; extreme aridity, stormy winds carrying dust storms emanate from the Sahel region. The pastoralist Hausa-Fulani who were displaced from northern harsh environment advance southward with families and livestock of cows, sheep, goats etc. to the southern States. In their movements, they encounter hostile indigenes whose farms and waters may be destroyed by livestock. Fights that may end in fatalities have been of regular outcome resulting in major and painful socioeconomic problems and losses of lives, property and farmlands of the people. The Federal and State governments and some individuals have been trying to tackle/ check the problems.

\section{Biodiversity changes in animal and forest elements and socioeconomic resources}

Anambra State is a good case example of a heavily-urbanizing third world environment or community with highly-aggressive agricultural, quasi-industrial and commercial activities practiced Statewide. Any proper evaluations and analyses of Biodiversity of the State must seriously-consider the natural changes and anthropogenic impacts of human beings within the Biospheric environment in terms of negative and positive changes that have severely-interfered with Nature over the years. Land space and other material features of the earth such as water, air/oxygen, soils, rocks etc. are fixed by nature while human population and its anthropogenic needs/activities have geometrically-changed and increased to outpace the needs and responses by nature. As a result of this geometrical outpacing growth in population and material needs by nature and man, human beings, animals, reptiles, fishes, birds, plant species in various shapes of micro, macro and mega sizes etc. have to struggle and sometimes adversely-interfere with their natural environments in order to survive and thrive. They are forced to tenaciously-adapt-to-live or eventuallydie-out. For an example, as a result of increase in population, more lands, marshlands, wetlands and forests have been lost as they have been cleared of vegetation for agriculture to plant more food to feed more mouths for subsistence; build more houses for more homesteads; construct more roads for movements and transportation etc. Massive deforestation for timber-harvesting and firewood for energy is also rife; thereby decimating forest life and its longevity. In urbanizing, peri-urban communities and commercial centres, industrial activities are ongoing whereby solid and liquid wastes are heavily-generated. They are usually-carelessly-disposed off along roadsides or into dry valleys or surface waters. ${ }^{4-7}$ There are many urbanizing towns and communities where several infrastructure of roads, bridges, drainages, telecommunication systems, water reservoirs, buildings, markets, industries, schools, churches, hospitals, playgrounds etc. are being put up aggressively. As a result, virgin lands and forests including those reserved for sacred shrines, cemeteries, bushes, marshes/swamps/ wetlands, lakes, springs etc are aggressively-cleared and destroyed. All these anthropogenic activities have adversely changed the Biodiversity of the total environment of Anambra State. The State's atmosphere, ground surface, surface waters, soil materials, rocks, 
groundwater resources, humans, plant and animal species and lives struggle to survive the adverse climatic changes and conditions.

\section{Ecological impacts and disasters as well as severe climate changes}

There are so many ecological problems that engineer Biodiversity changes in Anambra State and its environs. Some are brieflyhighlighted below. Unfortunately governments and the people (leadership and commoners) do not seem to care or understand the ensuing hazards to appreciate the ongoing vagaries of nature, their continued anthropogenic and destructive implications. There is a clear display of ignorance or laissez-faire attitude in taking serious actions to check or curtail consequent unavoidable destructions and possible extinction of various biotic/abiotic species that have been ongoing annually. Very high temperatures that are $30-40^{\circ} \mathrm{C}$, excessive aridity, low humidity and unbearable heat waves are commonplace annually during the dry season. These negatively-affect vegetation, farm crops, dry up shallow surface waters and watertable aquifer. As a result of impacts of climate change, temperatures have increased over the years up by $2^{0} \mathrm{C}$. Dust storms are regular during dry periods, covering landmass and forming irritating dust deposits. Large-scale deforestation, bush burning and excessive farming even at wrong localities are carried out annually thereby destroying virgin grounds, bushes and forests. Desertification impacts are felt in Anambra State where parts of the former Rainforest Belt have been replaced by Guinea savannah scrubland. Deforestation and urbanization are most active as many former rural communities of Obosi, Ogidi, Abagana, Ifite-Ukpo, Atani, Ihiala, Aguleri, Agulu, Ekwulobia, Uga, Umuchu, Achina, Umunze, Igbo-Ukwu, Nnobi, Oba etc. are actively being deforested and urbanized widely. These communities are knowingly or unknowingly interfering with or destroying the much-cherished ancient forests forever and rendering Biodiversity almost to nullity or extinction. Heavy and thunderous rainfall occurs for many months during the rainy season. The rains usher-in heavy flooding that generate excessive sheet, rill, soil, channel and gully erosion, landslides and massive transportation of sediments into valleys and surface waters. All these environmental hazards destroy and ravage the physical and Hydrogeologic environment. ${ }^{8-10}$ The massive soil and gully erosion also exacerbate the incidences of environmental pollution and contamination of lands and water courses through sediment transport and deposition. They silt up marsh/wetlands and turn streams, lakes and rivers into brownish or reddish colours making them eutrophic. They poison lives of humans, aquatic animals and plants such that many plants and fishes ultimately die. These events thereby display major threats and actual happenings to existing species of and growth in Biodiversity. A proper understanding of the biotic and physical environment is important to monitor and possibly-ameliorate the various forms of environmental degradation that destroy or change for worse its biotic life. ${ }^{11}$ Furthermore and similarly, industries and commercial concerns recklessly-dispose of their solid and liquid wastes on land or into nearby surface waters where they cause pollution and contamination and consequent losses in aquatic lives. ${ }^{12-16}$ The major gullies which advance frontally at the rate of about 4 to $8 \mathrm{~m}$ per year pull down trees and destroy bushes in ravaged areas and pushing them into gully-chasms where such trees and branches eventually die. ${ }^{17}$ Heavy loads of sediments carried by floods from gully sites are transported into lakes, streams and rivers where heavy siltation that pollute waters. The sediment-load smother biotic flora and fauna such that these animal and plants biota wither away and die. The concentrations of gully erosion and landslide in the area vary from areas of high hydraulic head to areas of low hydraulic head ${ }^{13}$ and display the rate and magnitude of gullying and destruction.

Deprivation, poverty, hunger, insecurity, ignorance, fraud, corruption etc. are also factors that harshly-affect management of problems that affect environmental hazards and Biodiversity. As a result of these socioeconomic ailments, people and governments are unable to positively and effectively-tackle the problems that cause disaffection in life of biota for them to reach appreciable growth and longevity in life. Flood disasters are annual events; ravages of soil and gully erosion and landslides are endemic all over Anambra State and beyond, causing loss of lives and destruction of houses and property worth trillions of Naira (billions of dollars). These problems have changed the Biodiversity features of the entire landscape. Ignorance, laissez-faire attitude and corruption are key factors that hazard control programmes as project funds may be mismanaged or be frittered away. Some professionals are poorly-trained such that they fail to understand the intricate inter-relationships over issues of Biodiversity, professional practices, ethics and environmental management. As a result of professional ineptitude, pride and ignorance, Biodiversity management eventually-suffers irreparable losses. Sometimes, provided funds may be misused or misappropriated such that what is required is not done. Again, contract projects may not be brought in close liaison to the attention and participation of communities that need the projects. Such projects suffer failures and incur losses even before conception. Attendant public health issues and possible emergence of esoteric diseases from transported plants and animals from desertified regions into Anambra State may also affect Biodiversity. ${ }^{18,19}$

\section{Environmental impacts on biodiversity changes in anambra state}

The following environmental major factors and impacts on Biodiversity changes in Anambra State and beyond may be of the essence:

Deforestation has caused great losses in different sizes and varieties of ancient plants, trees, shrubs, grasses that are of micro-, macro- and mega-sizes and shapes. Gigantic trees like oji (iroko), uku etc. have all been almost-harvested for timber; and have disappeared forever. Smaller trees have been cut down for firewood and use as sticks in farms. Bushes have been burned and cleared almost-annually for planting in Agriculture, buildings-homes and other infrastructure.

Some ancient forests, dedicated to gods-of-shrines of Archaeological rating and declared sacred covens, usually situated at headwaters of lakes, springs or streams on sandy/sedimentary Formations have been destroyed. People are barred from hunting in such sacred forests or fishing from the waters such that the ecosystem was protected, preserved and remained stable. As a result, wildlife was abundant while the flora and fauna thrived; but most of these have been destroyed and lost.

The preserved sacred shrine-forests protected the biota, springs, streams, lakes or rivers from overland pollution and contamination from floods, gully erosion and sedimentation and saved the areas from destruction. Today after deforestation and other adverse anthropogenic activities in such areas there are upsurges of mass wasting, soil/gully erosion, severe landslides and major losses in Biodiversity.

Deforestation has resulted in losses in wildlife through absence of habitats for big and small wild life of animals, reptiles, birds insects etc. Native hunting for wildlife has become a mirage and non-existent 
in Anambra State because of environmental destruction. Such animals as nchi (grasscutter), uze (squirrel), enwe (monkey), agwo (snakes of many kinds) and varieties of birds etc. do not exist anymore. The native hunters are pauperized and have been put out of business.

Deforestation has resulted in excessive loss of vegetation such that many species of medicinal plants and vegetables-for-foods have been lost permanently.

Forest resources in Anambra State and beyond have become very scarce. People travel quite far away to buy timber materials for civil constructions at high costs

Desertification in northern parts of Nigeria has rapidly-spread to the southern States including Anambra State. The harsh Guinea savannah environment has displaced the former Rainforest Belt that adorned parts of north Anambra area.

The movement of herdsmen from the north downsouth with their families, cows, goats, sheep etc. have adversely-affected the Biodiversity of the State. Instead of keeping secured their herds of cattle in ranches, they are moved along into urban and rural roads, across homes, streams and farms. They pass faecal matter into streams and on roads and damage them. They devour and destroy farm crops and pollute streams. These excesses in cattle-rearing activities cause quarrels and disagreements that result in injuries and fatalities with indigenous communities who own the land, farms and streams that are being destroyed.

These negatively-severe impacts of deforestation, erosion and pollution on Biodiversity such as sediment loading and absence of forest-covers increase losses in residential and agricultural lands through floods, soil and gully erosion. They also increase and exacerbate incidences of poverty, hunger, disease, insecurity, permanent losses in medicinal plants and herbs, food vegetables, destructions of animals, plants and water resources.

The most pathetic aspect is that these negative Biodiversity changes are of a permanent feature that is akin to possible major extinction of the period as the biotic life can be hardly-reversed. There is no serious attempts or programmes by anybody or governments to try and reverse them. Most of the lands have been left barren where they are not built up or where there are no ongoing agricultural practices.

There have been some efforts in northern States of Nigeria to establish Greenbelt Vegetation to check the vicious advance of Sahara desert. This laudable project is yet to be of any success. Today, one sees ill-looking remnants of the famous Rainforest Belt of Tropical West Africa and patches of vegetation around abandoned shrines or headwaters of almost dried-up springs, streams and lakes dotting the landscape.

One may conceptualize that a high estimate in magnitude of damages and losses have been caused in Biodiversity changes in Anambra State vis-a-vis the micro and macro-biota in Anambra State total environment and beyond. It is clear that the same or comparative magnitude of losses must have been suffered equally and equivalently by micro- and mega-scopic plants and animals.

\section{The holocene/recent biodiversity terminal-changes: suggestions and recommendations}

The Holocene or Recent time-period in the Geologic Time-Scale spans from the age of 10,000 years to the present time. The Holocene or Recent Biodiversity changes during this period in Anambra State and in other parts of Nigeria particularly in the northern States seem to have become terminal in nature. This is as a result of being exacerbated by the result of anthropogenic activities and Sahara desert encroachment southward of Nigeria through desertification. The chaotic processes in the present Biodiversity changes might be tending to a major mass permanent deaths or extinction of the various biota (plants and animal species). Those rare wild animals and plants that served diverse socioeconomic purposes have been lost in perpetuity and can hardly be reproduced of their kinds anymore. Desertification and climate change, exacerbated by anthropogenic activities, are precipitating these terminal biotic-to-abiotic changes in Anambra state and beyond. These may result in a major wave of Biodiversity extinction period for various animal and plant species for long period of Archaeological times. Parts of northern Nigeria have been turned into desertified Sahel Savannah while parts of southern Nigeria including Anambra State have been turned into harsh Guinea Savannah both with concomitant near-desert climate resulting in major losses in wildlife, plants and animals. At rate of desertification movement southward, it is possible in future that Guinea Savannah may be replaced later by Sahel Savannah resulting in more Biodiversity losses in Anambra State and beyond.

\section{These suggestions and recommendations for control measures may be considered}

International Aid Agencies, Federal and State governments of Nigeria, private aid agencies and individuals should enlarge and broaden their present and laudable Greenbelt Vegetation projects being carried out in parts of northern Nigeria to stop, check or slow down the aggressive and southward movement of Sahara desert. Possible check on desertification would enable some plant and animal species as well as total environment to recover and survive.

Excessive deforestation for urbanization, agricultural practices, harvesting of firewood and timber have been ongoing on a large scale all over Nigeria. This should be checked, controlled or stopped. The governments and people should massively-fund planting-up lands with vegetation of prime lands, open spaces etc.

Proper Environmental Impact Assessment (EIA) for identifying possible negative effects of development on Biodiversity during initiation and execution of projects should be carried out always in order to put in place control programmes that should enforce ameliorating measures against any destructive changes on the environment and that should be taken appropriately.

When controlling destructive impacts of natural and anthropogenic ecological disasters of climate change, floods, soil, gully erosion and landslides as well as environmental pollution and contamination, control measures should also consider taking into account measures to take care of possible negative impacts on Biodiversity changes that may arise and nip such problems in the bud. Efforts are made to check gullies but valuable actions are not taken to replant lost biota.

Developed nations and aid agencies of the United Nations and other world funding bodies should consider provisions of much needed funds to developing countries to support in tackling of their environmental scourges of disasters to save mammoth loses in global Biodiversity.

There is great need for international and national agencies to intensively-support and fund more studies and research on the impacts of ecological disasters/malaise on Biodiversity changes within the total environment; and encourage massive development of Greenbelt Vegetation in all affected and threatened environments. 
There is also great need for organizing national and international workshops, seminars, symposia, discussions and establishment of regional Data Banks on issues of Biodiversity changes in different parts of the world. Information gathered there-from would be usefully-help in successfully-tackling arising ecological problems locally, nationally, regionally, globally or worldwide.

\section{Acknowledgments}

The authors are grateful to Nnamdi Azikiwe University, Awka, Nigeria particularly to staff and students of Department of Geological Sciences \& sub-Department of Applied Geophysics for providing us with funding for laboratory and field studies and research and provision of conducive environment for teaching and research; and the Management and staff of the Department of Earth Sciences, University of Waterloo, Waterloo, Ontario, Canada for their commendable postgraduate/research collaboration and support.

\section{Conflicts of interest}

The author declares there is no conflicts of interest.

\section{References}

1. Aganigbo CI, Akudinobi BEB, Okoyeh EI. Hydrogeochemical Assessment of Mbanabor Area Anambra Basin Southeastern, Nigeria. Jour of Natural Sci Research. 2016;6(8):56-67.

2. Okoyeh EI, Akpan AE, Egboka BCE, et al. An Assessment of the Influence of Surface and Subsurface water level Dynamics in the Development of Gully in Anambra State Southeastern, Nigeria. Earth Interactions. 2014;18(4):1-24.

3. Nwajide CS. Geology of Nigeria's Sedimentary Basins. CSS Bookshops Limited Lagos. 2014;5(1):382-392.

4. Egboka BCE, Okoyeh EI. The Impacts and Implications of Anthropogenic Forces on the Unstable Geologic Platform in parts of Anambra and Imo States Southeastern, Nigeria. Int'l Jour of Environ Protection and Policy. 2016;4(4):104-110.

5. Egboka BCE, Odoh BI. Ecological Disasters and Sustainable Development. In BCE Egboka, BI Odoh, Editors. Water: Ecological Disasters and Sustainable Development (Monograph). Germany, UK, USA: LAP Lambert Academic Publishing. 2011.

6. Orajaka IP, Egboka BCE, Onwuemesi AG, et al. Coal Resource of Nigeria and Economic Importance. Mining Magazine J. 1990;451.
7. Uma KO, Onuoha KM, Egboka BCE. Hydrochemical facies, groundwater flow pattern and origin of saline waters in parts of the western flank of the Cross River Basin, Nigeria. Earth Evolution Science Monograph Series. $1989 ; 20$.

8. Egboka BCE, Anike OL. Rainwater-wasted and Environmental Hazards in Anambra State of Nigeria. Journal of Rainwater Catchment Systems. 1993;1(2):65-69.

9. Egboka BCE, Anike OL. An integrated flood and storm water mitigation and environmental management in Anambra State, Nigeria. Proceedings of Stockholm Water Symposium. 1994;579-588.

10. Nwankwor GI, BCE Egboka. Leakage properties of a water supply multi-aquifer system in Onitsha Area, Anambra State, Nigeria. Journal of Hydrological Sciences Journal. 1992;37(6):557-566.

11. Chibuzor S, Okoyeh E, Egboka BCE. Evaluation of the causes of Environmental Degradation in parts of Southeast, Nigeria. Int'l Jour of Innovation research and advance studies. 2017;4(11):407-411.

12. Akudinobi BEB, BCE Egboka. Gully Erosion in the Old Anambra State: Anthropogenic and Geotechnical considerations. 1994.

13. Egboka BCE, EI Okoro. Basin Groundwater Recharge and Discharge at the Gully Erosion Prone Areas of Anambra State, Nigeria. Journal of Environmental Science \& Engineering. 2011;5(7):925.

14. Egboka BCE, E Mbanugoh. Anthropogenically-caused road gullies in Anambra State, Nigeria. Indian Journal of Earth Sciences. 1988;13(4):316-332.

15. Egboka BCE. The Hydrogeological Provinces of Nigeria. 1988;13(4):117-125.

16. Egboka BCE. Some World Geologists/Geophysicists/Seismologists/ Political Leaders to blame over the Japanese triple ecological tragedy. Earth Sciences. 2011.

17. Onwuemesi AG, BCE Egboka. 2-D polynomial curve-fitting on watertable and estimation of hydraulic gradient estimation in Anambra State, Nigeria. J. African Earth Sciences. 2010.

18. Okoyeh EI, Ejezie OE, Ezeh HN, et al. Evaluation of Ihiala Laterites for Use as Sub-grade Material in Road Construction. Jour of Geo, Environ Earth Sci International. 2017;12(3):1-9.

19. Okoyeh EI, Akpan AE, Egboka BCE, et al. Dimensional Analysis and Characterization of the Gully Systems in parts of Southeastern Nigeria, In: Egboka BCE, Odoh BI, Editors. Water: Ecological Disasters and Sustainable Development (Monograph). LAP Lambert Academic Publishing, Germany, UK, USA, 2011. 